\title{
The Wolf-Pack Case and the Reform of Sex Crimes in Spain
}

\author{
Patricia Faraldo-Cabana ${ }^{1,2}$ \\ ${ }^{1}$ Department of Public Law, Universidade da Coruña, A Coruña, Spain; and ${ }^{2}$ School of Justice, Queensland University of \\ Technology, Brisbane, Australia \\ Corresponding author: patricia.faraldo@udc.es
}

(Received 19 June 2021; accepted 23 June 2021)

\begin{abstract}
The controversial trial of five men accused of gang-raping a young woman during the 2016 San Fermín festival and their conviction not for rape, but for a lesser crime of sexual abuse in 2018, known as La Manada (the Wolf-Pack) case, brought the Spanish law under intense public scrutiny. The case led to an outpouring of protests across the country and called for the urgent reform of rape laws, which then led to the drafting of new provisions to address the outcry. To set the analysis in the context of feminist activism, this Article is organized around the hashtags used during the protests. Accordingly, this Article examines three aspects of considerable debate: Namely the distinction between sexual abuse and rape ("it's not abuse, it's rape!"), the murky legal understanding of consent ("only yes is yes"), and the introduction of the gender perspective in the legal system ("sister, I believe you"). By addressing these issues, this Article demonstrates the pervasive influence of feminism over recent Spanish law-making, and the continued resistance which such efforts meet. This Article concludes by scrutinizing this effect and examining the conditions under which a civil society network may succeed in challenging socially outdated legal provisions.
\end{abstract}

Keywords: Rape; Wolf-Pack Case; MeToo; Sex Crimes; Consent

\section{A. Introduction}

After an overwhelming majority of academia approved of and praised extensive reforms of rape laws in 1989 and 1995-and subsequent revisions in 1999, 2003, and 2010 - few voices raised objections or advocated changes in the Spanish criminal justice system regarding sex crimes. Only a minority of feminist lawyers and scholars maintained that the statutes and the criminal justice system continued to reflect a legacy of patriarchy, employing assumptions and standards about consent, force, resistance, and "proper" behavior of victims that were biased against women in cases of sexual violence. It was generally ignored that the standards of rape law and the procedures to enforce those standards failed to account for the perspective and interests of women.

This situation of self-complacency radically changed in 2016. The turning point was the controversial trial of five men accused of gang-raping a young woman during the San Fermín (Running-with-the-Bulls) festivities in July of that year in Pamplona. They led her into the lobby of a residential building, undressed her and took turns having sex with her, penetrating her at least ten times in less than thirty minutes, vaginally, orally, and anally without using a condom. Frozen 
in shock, she shut her eyes and waited for it to end. Two of the men recorded 96 seconds of the incident with their cell phones. One of them sent celebratory messages about their "conquest" on his WhatsApp chat in the hours after the rape: "Good morning. The five of us fucked one girl. Hahaha." "We have video," he added. By that evening, the five were already behind bars. The case is known as La Manada, or the Wolf-Pack case, because the men called themselves so in their WhatsApp chat group. In April 2018, the five men were acquitted of rape on the grounds that they did not employ violence or intimidation to subjugate the victim. The Pamplona-based court ruled that they were guilty only of the lesser crime of sexual abuse and sentenced them to nine years in prison. This first ruling was upheld in an appellate court. In the last and definitive decision handed down in June 2019, the Spanish Supreme Court reversed the lower courts and affirmed that the men were guilty of rape, sentencing them to fifteen years in prison.

The massive public reaction to the case sparked an extraordinary social movement. For many women across the country, even before the final verdict was handed down, the case had been a moment of reckoning, laying bare a deep culture of misogyny both in Spanish society and the criminal justice system. A tremendous indignation at a patriarchal system that neither protects nor believes assaulted women triggered mass protests. An unprecedented, emboldened feminist movement geared up and organized protests, calling for Spain's sexual assault laws to be rewritten as a sign of solidarity with the case's victim. Such a call fell into line with sex laws changing in European countries, such as Germany ${ }^{1}$ and Sweden. ${ }^{2}$ In other countries, like Denmark, Finland, Greece, and Portugal, legislators are considering amendments to ensure that such offenses are based on the absence of the victim's free consent. The urgency of these legal contemplations is boosted by the enactment of the Council of Europe's Convention on Combatting and Preventing Violence against Women and Domestic Violence (hereinafter Istanbul Convention) in 2011.

Intense scrutiny by the international press $^{3}$ in the wake of the \#MeToo movement and international condemnations ${ }^{4}$ of the Wolf-Pack verdict influenced the Spanish reassessment of Spain's laws on rape. Only a few days after having applauded the sentence as "harsh enough," Rafael Catalá, the Minister of Justice in Minister President Rajoy's right-wing government, ordered the codification commission - a ministry advisory body - to evaluate a potential revision to the Penal Code ${ }^{5}$ in terms of the categorization of sex crimes. ${ }^{6}$ The report was submitted to the

\footnotetext{
${ }^{1}$ See Tatjana Hörnle, The New German Law on Sexual Assault and Sexual Harassment, 18 German L.J. 1309-30 (2017).

${ }^{2}$ See Gabriella Nilsson, Towards Voluntariness in Swedish Rape Law: Hyper-medialised Group Rape Cases and the Shift in the Legal Discourse, in Rape In THE Nordic Countries: Continuity and Change 101-19 (Marie Bruvik Heinskou, May-Len Skilbrei, \& Kari Stefansen eds., 2020).

${ }^{3}$ See, e.g., Valentina Barresi, Pamplona, il processo per stuprp al "Branco" che scuote la Spagna, LA RePUBBLICA, Nov. 29, 2017, https://www.repubblica.it/esteri/2017/11/29/news/spagna_processo_stupro_branco-182516897/?ref=drac-3; Yohan Blavignat, Espagne: colère après la condamnation de «la meute» pour abus sexuels, LE FigARò, Apr. 26, 2018, https://www. lefigaro.fr/international/2018/04/26/01003-20180426ARTFIG00367-espagne-manifestations-apres-la-condamnation-dela-meute-pour-abus-sexuels.php; Sam Jones, Protests in Spain as Five Men Cleared of Teenager's Gang Rape, THE GuARDIAN, Apr. 26, 2018, https://www.theguardian.com/world/2018/apr/26/protests-spain-five-men-cleared-of-teenagers-gang-rapepamplona; Raphael Minder, Spanish Court Sentences Pamplona 'Wolf Pack' to 15 Years for Rape, N.Y. TimES, June 21, 2019, https://www.nytimes.com/2019/06/21/world/europe/spain-wolf-pack-pamplona-rape.html.

${ }^{4}$ See Purna Sen, Statement from Purna Sen, UN Women's Executive Coordinator and Spokesperson on Sexual Harassment and Other Forms of Discrimination, UNWOMEN, May 7, 2018, https://www.unwomen.org/en/news/stories/2018/5/statementpurna-sen-sexual-harassment-and-discrimination (speaking of “the light sentencing of the wolf pack' attackers in Spain" that "diminishes the severity of the violation and undermines clear obligations to uphold the rights of women"). After the second ruling, Vera Jourová, the EU commissioner for Justice and Gender Equality, asked the Spanish judiciary to make a "quick and fair" decision on the prosecutor's appeal, and expressed hope that the victim should recover "physically and emotionally as quickly as possible." ACN, One in four rape victims in Catalonia is under 18, CatalanNews, May 3, 2018, https://www. catalannews.com/society-science/item/one-in-four-rape-victims-in-catalonia-is-under- 18.

${ }^{5}$ See C.P., B.O.E., LeY ORGÁNICA 10 (Nov. 23, 1995) (Spain). https://www.boe.es/eli/es/lo/1995/11/23/10/con.

${ }^{6}$ Manuel Barranco, Catalá asegura que el Gobierno tendrá en "semanas" una primera propuesta de reforma del Código Penal, EL Mundo, Apr. 20, 2018, http://www.elmundo.es/espana/2018/04/29/5ae51458268e3ed23d8b4686.html.
} 
following Minister of Justice, Dolores Delgado, from the Socialist Party. Within months, both the far-left Podemos party and the right-wing Popular Party vowed to change Spain's rape law and presented reform proposals. ${ }^{7}$ Plans to improve the system, however, hung in the air for months, as the national parliament remained in a deadlock due to political instability. After a new socialist-led coalition government took power in January 2020, the Equality Minister Irene Montero, acting on a pre-election promise to strengthen laws in defense of women's rights, promoted a Sexual Freedom draft bill that defines all non-consensual sex as sexual aggression and, in cases of penetration, as rape. Even though the draft must be examined by two state commissions before being voted on by Spanish Parliament—a minimum six-month process - it has already prompted strong criticism from the conservative right in Spain and triggered the first major dispute between the two partners in Spain's leftist coalition government, ${ }^{8}$ reflecting how significant the feminism issue is in Spain.

\section{B. The Emperor's New Clothes: Sex Crimes in the Spanish Penal Code}

Sex crimes, including rape, are regulated under Article 178, of the Spanish Penal Code. ${ }^{9}$ Article 178 introduces a distinction between "sexual aggression" and "sexual abuse" that is very important for the purpose of this Article, as it lies at the core of the protests against the Wolf-Pack verdict.

A person shall be guilty of a sexual aggression when that person offends against the sexual freedom of another person using violence or intimidation. Violence and intimidation correspond with each other as they both contain elements of coercion, injury, and threats. It must be clear that these elements are effective and sufficient to overcome the will of the victim. It is necessary that, but for the violence or intimidation caused by the accused, the victim would not have been assaulted. When found guilty, a person shall be punished for sexual aggression with a sentence of imprisonment from one to five years. When the sexual aggression consists of penile-vaginal, anal, or oral penetration, or inserting body parts or objects into either of the former two orifices, the offender shall be convicted of rape, also called "aggravated sexual aggression," with a sentence of imprisonment from six to twelve years, which is extended from twelve to fifteen years in cases of special circumstances. ${ }^{10}$

Besides sexual aggression, the Spanish Penal Code contains a second category of offenses labeled "sexual abuse." Whoever, without violence or intimidation, perpetrates non-consensual acts against the sexual freedom of another person, shall be convicted of sexual abuse with a sentence of imprisonment from one to three years or a fine of eighteen to twenty-four months. Nonconsensual sexual abuse also includes acts perpetrated on persons who are unconscious or whose mental disorder is taken advantage of, and those committed by overcoming the will of the victim using narcotics, drugs, or any other natural or chemical substance that can be used for such

\footnotetext{
${ }^{7}$ See Proposición de Ley de Protección Integral de la Libertad Sexual y para la erradicación de las violencias sexuales (July 20, 2018) http://www.congreso.es/public_oficiales/L12/CONG/BOCG/B/BOCG-12-B-297-1.PDF; Proposición de Ley Orgánica de modificación de la Ley Orgánica 10/1995, de 23 de noviembre, del Código Penal, en materia de delitos contra la libertad sexual (Dec. 2018) http://www.congreso.es/portal/page/portal/Congreso/PopUpCGI?CMD=VERLST\&BASE=pu12\&DOCS=1-1\& DOCORDER=LIFO\&QUERY=\%28BOCG-12-B-357-1.CODI.\%29.

${ }^{8}$ Guy Hedgecoe, Spain's Coalition Partners Lock Horns Over Gender Violence Policy, THE IRISH Times, Mar. 5, 2020, https:// www.irishtimes.com/news/world/europe/spain-s-coalition-partners-lock-horns-over-gender-violence-policy-1.4194283.

${ }^{9}$ See 8 Código Penal [C.P.] [Criminal Code] art. 178 (1995) (Spain).

${ }^{10}$ The special circumstances are: When the violence or intimidation made are of a particularly degrading or humiliating nature; When the acts are committed by joint action of two or more persons; When the victim is especially vulnerable due to age, illness, handicap or circumstances, except for what is set forth in Article 183; When, in order to execute the offence, the offender has availed himself of a superiority or relationship, due to being the ascendant, descendent or brother or sister, biological or adopted or in-law of the victim; When the doer uses weapons or other equally dangerous means which may cause death or any of the injuries foreseen in Articles 149 and 150 of this Code, without prejudice to the relevant punishment for the death or injuries caused. Should two or more of the above circumstances concur, the penalties foreseen in this Article shall be imposed in the upper half.
} 
purpose. The same punishment is imposed when consent is obtained by an offender availing himself of a situation of manifest superiority that deprives the victim of liberty. Again, whenever the sexual abuse consists of penile-vaginal, anal, or oral penetration, or inserting body parts or objects into either the vagina or the anus, the person shall be convicted of aggravated sexual abuse with a sentence of imprisonment from four to ten years. Alongside these provisions, the Spanish Penal Code also dedicates some articles, specifically, to sexual abuse, sexual aggression, and other sexual offenses perpetrated against children under the age of sixteen and, separately, children between the ages of sixteen and eighteen.

As we can see, both sexual aggression and sexual abuse include penetrative and non-penetrative offenses. The difference between sexual aggression and sexual abuse is centered only in the use of violence or intimidation. Spain, like other EU member states, legally recognizes an assault as rape -also called aggravated sexual aggression—only when unwanted oral, anal, or vaginal penetration is achieved through violence or intimidation.

This was not always the case. In fact, the traditional definition of rape in Spain was not based on the coercion model. Until 1989, rape was defined as the penile-vaginal sexual intercourse with a woman by means of force or intimidation, or sexual intercourse with an unconscious or mentally incapacitated woman or with a girl under twelve. Therefore, rape was defined in terms of both force or lack of consent, including cases in which the victim - always a female-did not have the opportunity to express her opinion due to being asleep, drugged, or drunk, or may have even agreed to the sexual intercourse, but such agreement was legally deemed non-valid because of her mental illness or juvenile status. In cases where the victim of the penetrative assault was a male, or the physical act performed was not penile-vaginal sexual intercourse, the crime was called "indecent assault" and punished with a lesser penalty. Some features were modernized in 1989, mainly by describing offenders and victims in a gender-neutral way and including in the legal definition of sexual intercourse penetration with the penis or an object of the vagina, anus, or mouth. ${ }^{11}$ These changes were partly promoted by the feminist movement, ${ }^{12}$ which had been raising objections and advocating changes in rape law since the late 1970s. They were welcomed in literature. ${ }^{13}$ In 1995, the new Penal Code changed the definition of sex crimes, introducing the current difference between sexual abuse and sexual aggression based on the presence of violence or intimidation. Another reform was to re-label "rape" as an aggravated sexual aggression. Following the enactment of the 1995 Penal Code, the law of sex crimes was subject to continuous scrutiny and significant reforms, with the definition of rape evolving considerably over the years. Revisions concerned, among other things, the use of the word "rape," 14 the elimination of the oral

\footnotetext{
${ }^{11}$ This extension in the range of objects and orifices within the concept of rape contributed to de-gendering the definition of rape in relation to both the victim and the perpetrator.

${ }^{12}$ For instance, concern for gender equality led to the design of gender-neutral statutes, thus replacing traditional definitions which punished the rape of a woman by a man with gender-neutral definitions. Support for gender-neutral statutes was, at the time, quite common in literature. See Javier Boix Reig, Enrique Orts Berenguer \& Tomas Salvador Vives Anton, La Reforma Penal de 1989, 138 (1989); La Reforma Penal de 1989 30-31 (Francisco Muñoz Conde ed., 1989). Only a few voices signaled that women were disadvantaged by such statutes. See Elena Larrauri, Control formal: . . y el derecho penal de las mujeres, in Mujeres, Derecho penal y Criminología 93, 96 (1994); Adela Asúa Batarrita, Las agresiones sexuales en el nuevo Código Penal: imágenes culturales y discurso jurídico, in ANÁLISIS DEL CÓDIGO PENAL DESDE LA PERSPECTIVA DE GÉNERO 45, 89 (1998) (writing from the perspective that to hide the gendered reality of sexual assault only means retaining male reactions as the norm for what a typical victim's reaction to attack should be).

${ }^{13}$ See BoIX ReIG et al., supra note 12, at 136-38; Muñoz Conde, supra note 12, at 30-31.

${ }^{14}$ It had been eliminated in 1995 on the grounds that it was traditionally linked to penile-vaginal penetration, which was only justified on the basis of a protection centered on the female reproductive function and the need to avoid risks of illegitimate pregnancy and disease transmission. See Juan José González Rus, Los delitos contra la libertad sexual en el Código penal de 1995, 59 Cuad. Polit. Crim. 321, 335 (1996); Diego lópez Garrido \& Mercedes García Arán, El Código Penal DE 1995 y la Voluntad del Legislador 109 (1996); María Luisa Maqueda Abreu, La regulación legal de las agresiones y abusos sexuales, 33 MERIDIAM 40, 43 (2004). The word "rape" was reintroduced in 1999, in what was understood as a "nostalgic gesture” with no further meaning. See, e.g., Javier Boix Reig \& Enrique Orts Berenguer, Consideraciones sobre la reforma
} 
penetration with objects as a form of rape or aggravated sexual abuse, ${ }^{15}$ the inclusion of vaginal and anal penetration with "body parts" other than the penis as a form of rape or aggravated sexual abuse, ${ }^{16}$ and the introduction of the use of substances to overcome the victim's will as a form of sexual abuse, not rape. ${ }^{17}$ These reforms mainly responded to legal technicalities. Feminist voices in civil society ${ }^{18}$ and academia ${ }^{19}$ denounced rape statutes and the criminal justice system as continuing to reflect a legacy of patriarchy and reflecting a disappointing lack of respect for women's sexual autonomy that went utterly unattended by reforms. Proposed changes to the law relating to the introduction of a definition of consent and a move towards an affirmative consent standard in order to challenge mistaken assumptions and myths regarding rape were rejected. Arguments in favor of an approach to sexual violence that de-centered penetration and, thus, challenged traditional understandings of rape received no answer. ${ }^{20}$ Concerns regarding the extent to which the notion of false allegations of rape continues to pervade the public and legal imagination, negatively impacting women involved in the criminal justice system and crashing against offenders' right to a fair trial and the presumption of innocence. ${ }^{21}$

\section{The Emperor Wears No Clothes: The Wolf-Pack Case}

This situation of relative placidity abruptly changed in 2016. The Wolf-Pack case offered the perfect example for feminist complaints directed both against a gender-blind law and a gender-biased case law that failed to protect women's sexual freedom. With an incident-specific focus, a new generation of feminist activists engaged in wider critiques of the societal attitudes that support and perpetuate not only rape, but all the many forms of violence against and oppression of women. Mass nationwide protests showed a profound discontent with the legal regulation of sex crimes in Spain, with media coverage playing a pivotal role in public discourse and the term "wolf pack" becoming shorthand for any alleged multiple perpetrator sexual assault.

What was the spark that lit such a fire? Three aspects galvanized feminists in Spain like never before. ${ }^{22}$ First, allegations by the men's lawyer, calling the incident "consensual sexual relations among six adults" and suggesting that the plaintiff only denounced the incident out of fear that the men would leak videos of the act. Second, the admission as evidence-by the Provincial Court of

de los delitos contra la libertad sexual, por la Ley Orgánica 11/1999, in El NUEVO DERECHO PENAL EsPAñOL; ESTUDIOS PENALES en memoria del Profesor José Manuel Valle MuñIz 1007, 1017 (Gonzalo Quintero Olivares \& Fermín Morales Prats eds., 2001); Viviana Caruso Fontán, Nuevas perspectivas sobre los delitos CONTRa la libertad Sexual 221 (2006).

${ }^{15}$ It had been heavily criticized since its introduction in 1989 on the grounds that it should properly be treated separately from other penetrative assaults, because of its less serious nature and greater difficulty to prove. See Avelina Alonso de Escamilla, El delito de violación: la conducta típica, XLII ANUARIo de Derecho PenAl y Ciencias Penales 571, 589 (1989); Manuel Cancio Meliá, Delitos contra la libertad sexual, in Comentarios AL Código Penal 514, 525-26 (Gonzalo Rodríguez Mourullo ed., 1997); Enrique Orts Berenguer, Delitos Contra la libertad SeXual 27 (1995).

${ }^{16}$ In 2003, the Spanish Supreme Court rejected to consider fingers as "objects," so that vaginal or anal penetration of children with fingers was not considered rape. See S.T.S., Feb. 14, 1994 (R.J., No. 314) (Spain); S.T.S., Mar. 23, 1999 (R.J., No. 2676) (Spain). The Public Prosecution Service and part of literature agreed with this interpretation. See Fiscalía General del Estado [State Attorney General's Office], 1990, Circular 2/1990 (Spain); Boix Reig \& Orts Berenguer, supra note 14, at 1018. It is still deemed questionable whether the tongue is a body member.

${ }^{17}$ This occurred in 2010. Cases of chemical submission, or drug-facilitated sexual assault, began to attract attention in the late 2000s. The case law was contradictory, with some sentences considering it sexual abuse and others sexual aggression. See S.T.S., Jan. 23, 2004 (R.J., No. 2174) (Spain); S.T.S., May 22, 2006 (R.J., No. 3314) (Spain).

${ }^{18}$ For example, associations such as Dones Juristes (Women Jurists) and Mujeres Juristas Themis.

${ }^{19}$ Such as Antígona, a research group affiliated with the University of Barcelona that has been pushing to change the way the legal system handles rape prosecutions for more than a decade.

${ }^{20}$ See, e.g., Asúa Batarrita, supra note 12.

${ }^{21}$ See Encarna Bodelón, Cuestionamiento de la eficacia del Derecho penal en relación a la protección de los intereses de las mujeres, 125 Delito y Sociedad 11-12 (1998).

${ }^{22}$ See James Badcock, Pamplona 'Wolf Pack' Gang Rape Trial Angers Spain, BBC, Nov. 28, 2017, https://www.bbc.com/ news/world-europe-42149912. 
Navarre-of reports and investigations into the victim's sexual history and her behavior after the incident that showed her having fun in the months following the attack and, at the same time, deeming the personal lives and social media activities of the accused as generally irrelevant. This included messages on the Wolf Pack's WhatsApp chat in which the men explicitly bragged about raping women and talked of purchasing date-rape drugs. And third, the court's rejection of keeping the five men in pre-trial custody, as requested by the public prosecutor and other private prosecutors in the case, even though they were already suspected of having committed another sex crime in May 2016 in Pozoblanco, only two months before the assault in Pamplona, as images they recorded and sent to their friends demonstrated. The court argued that it granted bail, because the men had no previous criminal records for sex crimes and the social pressure on them made it "practically unthinkable" that they would risk reoffending.

In the first ruling, made public in April 2018, the Provincial Court of Navarre found there to be insufficient evidence of force, threat, or physical coercion. The court said that, according to case law, there can only be violence if physical aggression is used against a victim-an act the court believed did not occur. On the question of intimidation - the key issue of the case-the court ruled that, according to case law, it is "psychological duress, consisting of the threat or the announcement of future and real serious harm if the victim does not agree to participate in a determined sexual act." The court agreed that the men had "taken advantage" of their superior position to sexually abuse the woman but ruled that this did not constitute intimidation. It said the "victim was not capable of explaining what harm she feared would happen, if she had disagreed to take part." Acquittal of rape was also based on the argument that the perpetrators could not have realized she did not consent due to her lack of protest or resistance. The victim's behavior in the video footage was "passive or neutral," as she kept her eyes closed at all times and remained silent and submissive. She, for her part, told the court that she froze in terror. The court found the men guilty of the "continuous sexual abuse" of the woman, a lesser crime under Spanish law. They each received nine-year prison sentences. One of the judges at the time even argued that the men should have been cleared of all charges, except the theft of her cell phone by one of the men after the assault. In his dissenting opinion, he commented that all he could see in the videos taken by the men was "an atmosphere of revelry and joy." He claimed the plaintiff exhibited "a total lack of inhibition ... in a joyous environment."

The ruling dramatically showed the extent to which gendered assumptions about what is intimidating and how a victim of rape should react still permeated and influenced the operation of criminal court proceedings and their outcomes. Immediately after the five men's convictions not for rape, but for the lesser crime of sexual abuse, hundreds of thousands of women took to the streets in protest: In a strong wave of support to the victim, shouting, "Sister, I believe you," and "Don't worry, sister, we are your wolf pack," criticizing the misogynic interpretation of the law — "It's not abuse, it's rape!"-and demanding a paradigm change in rape laws_-"Only yes is yes." Women's groups blasted the trial for being a cross-examination of the victim and started Spain's very own \#MeToo movement, sharing their personal experiences of sexual assault and harassment by using the hashtag \#Cuéntalo (Tell it) in another powerful display of solidarity with the victim.

The Navarre High Court basically confirmed the first ruling in December 2018. In July 2019, the Supreme Court overturned the lower court's verdict and found the five men guilty of rape rather than sexual abuse. It increased their sentences from nine to 15 years in prison. The Supreme Court deemed that footage filmed by the attackers on their mobile phones showed a genuinely "intimidating" atmosphere, in which the victim at no time consented to the sexual acts carried out by the accused, but was compelled to submit "to an overwhelming situation of physical and numerical superiority," after "recognition of the impossibility of opposing the lewd intentions 
of the aggressors." Further, it noted that "submission" or "surrender" are examples of nonconsent.

Confirmation that the Spanish criminal justice system can put the label of rape on the WolfPack case did not stop protests, which were further fueled by extensive media coverage on other gang assaults and resulting convictions of sexual abuse, not rape. ${ }^{23}$ After years of pushing for a gender-oriented legal reform, feminist lawyers seized on the momentum to finally get it done.

\section{1. "It's not abuse, it's rape!": The Blurry Distinction Between Sexual Abuse and Rape}

The Wolf-Pack case revealed gaping holes in the Spanish legal system's approach to sex crimes. As we have seen, in Spain the pivotal element of the sexual aggression definition, of which rape is an aggravated case, is the use of violence or intimidation. Such a differentiation between sexual abuse and sexual aggression based on the use of violence or intimidation was unanimously applauded at the time of the enactment of the 1995 Penal Code. ${ }^{24}$ It was argued that it duly emphasized the different scale of seriousness according to the impact on the victim's sexual autonomy, because it is not the same to be forced into submission through violence or threats than non-consensual sex. Nowadays, the distinction is still considered by some as "a sign of civilization and of efficiency." 25

Contrarily, during demonstrations against the Wolf-Pack rulings, Spanish law was severely criticized for not legally recognizing a sexual assault as rape unless violence or intimidation is employed, showing that the range of sexual violence that is labelled as rape by Spanish criminal law is too narrow. Even though there is no resistance requirement in Spanish rape law, silence or verbal protests do not qualify as sufficient for a rape conviction. Usually, only physical resistance does. Establishing that sexual intercourse occurred while the complainant is intimidated is a major hurdle for the prosecution, particularly when the victim did not resist or demonstrate her lack of consent. The court agreed that the men had "taken advantage" of their superior position to sexually abuse the woman, but ruled that this did not constitute intimidation, understood, according to case law, as "psychological duress, consisting of the threat or the announcement of future and real serious harm if the victim does not agree to participate in a determined sexual act." Courts' restricted definition of intimidation outraged protesters. Moreover, requirements made by the judiciary in the first two rulings of the Wolf-Pack case clearly embodied a male perception of threatening situations and a male way of responding to a threatening situation. Paraphrasing Estrich, ${ }^{26}$ a good victim fights back, she does not submit: "[S] he is a real man." The fact that many women do not respond with physical force or verbal protests to a threatening situation, but crying or freezing in shock, as the Wolf-Pack's victim did, was not taken into consideration, even though "involuntary paralysis" or "tonic immobility" has been recognized by experts as a very common physiological and psychological response to sexual assault. ${ }^{27}$ In the Wolf-Pack case, according to the Provincial Court of Pamplona, rape did not occur since the victim had not been forced nor had she resisted. Although two of the three presiding judges in this first ruling conceded that they believed the complainant had not consented to the act, the fact that she had not been violently coerced or intimidated prevented them from qualifying it as rape. This did not mean that the

\footnotetext{
${ }^{23}$ See, e.g., Zamira Rahim, Outrage After Men Found Guilty of Sexual Abuse not Rape as Victim was 'Unconscious,' INDEPENDENT, Nov. 1, 2019, https://www.independent.co.uk/news/world/europe/spain-gang-rape-case-manresa-wolf-packsexual-abuse-barcelona-court-a9180776.html.

${ }^{24}$ Fermín Morales Prats \& Ramón García Albero, Título VIII, in Comentarios al Nuevo Código Penal 871,874 (Gonzalo Quintero Olivares ed., 1996); Cancio Meliá, supra note 15, at 522.

${ }^{25} J u a n$ Antonio Lascuraín Sánchez, Las huellas de "La Manada," 77 Cronista Estado Soc. 16, 19 (2018).

${ }^{26}$ SusAn Estrich, ReAl RAPe 45 (1987).

${ }^{27}$ See Arturo Bados, Lidia Toribio \& Eugeni García-Grau, Traumatic Events and Tonic Immobility, 11 SPAN. J. PsYCH. 516-21 (2008); Moriah Schiewe, Tonic Immobility: The Fear-Freeze Response as a Forgotten Factor in Sexual Assault Laws, 8 DEPAUL J. Women, Gender \& L. 1-29 (2019); Sunda Friedman TeBockhorst, Mary Sean O'Halloran \& Blair N. Nyline, Tonic Immobility Among Survivors of Sexual Assault, 7 Psych. Trauma 171-78 (2015).
} 
victim went totally unprotected, because the five men were found guilty of sexual abuse, but their penalty was significantly lower.

\section{II. "Only yes is yes": The Murky Understanding of Consent}

In a society where the specter of Franco's patriarchal, fascist regime lingers, Spanish sex crime law rests on the misogynistic implication that women are passive and submissive sexual partners. As such, their bodies are sexually accessible for women exist in a state of consent. ${ }^{28}$ Therefore, their passivity is equivalent to consent, which is eventually vitiated and invalidated whenever the defendant avails himself of a situation of manifest superiority. In the first two rulings of the Wolf-Pack case, although the complainant was under no legal obligation to expressly signal her non-consent or show physical resistance, the burden of proof meant that she was effectively treated as having consented. The prosecution could not prove otherwise, even though both the Provincial Court and the High Court of Navarre considered her "consent" vitiated by a situation of manifest superiority that deprived her of liberty. This approach made protesters' blood boil. In July 2018, after the first ruling, the Spanish vice-president Carmen Calvo announced a progressive reform requiring affirmative consent, which would be a major revision in the sexual assault laws in Spain. ${ }^{29}$ The reaction was immediate. She became the very epitome of the ridiculousness of feminism, with both men and women laughing at the idea of a sex contract or a consent app, and the proposal received vitriolic criticisms by right-wing media and parties. ${ }^{30}$ Even if the contract version of the affirmative consent is largely a product of the derisive discourse of reform opponents who seek to make a mockery of the standard, ${ }^{31}$ the concept of requiring a "yes" before sex is nearly unanimously rejected by lawyers and judges, ${ }^{32}$ and continues to engender public disdain. Popular opinion appears to be that requiring a "yes" before intercourse is totally inappropriate and unfair, as well as unrealistic and artificial. Moreover, the Supreme Court's rejection of the defense of implicit consent in the Wolf-Pack case casts doubts on the need for a legal change. After all, its ruling, applying the existing, unreformed rape law, expressly says that "only yes is yes," such that the victim's passive and submissive attitude should not be interpreted as consent.

Certainly, consent is a threshold that can only be invoked with caution. One could say that affirmative consent does not solve all problems. It has been said that it places too high a level of responsibility on the defendant to ensure that the complainant consented. ${ }^{33}$ Even though there needs to be only some evidence of a mistaken belief of consent to prove that the defendant believed that consent had been given, this is thought to be too strict of a standard. From another perspective, it has also been maintained that the influence of external pressures on personal selfdetermination makes it necessary to scrutinize every "yes," which should not be taken at face value. Contextual circumstances, such as power disparities, relational dynamics, material inequalities, and socio-sexual norms, may lead to questions of whether the woman was in fact capable

\footnotetext{
${ }^{28}$ See Eduardo Ramon Ribas \& Patricia Faraldo Cabana, "Solo sí es sí," pero de verdad, XL EstUdios PENALES Y CRIMINOLÓGICOS 21, 33 (2020).

${ }^{29}$ See Stephen Burgen, Spain to Introduce 'Yes Means Yes' Sexual Consent Law, The GuArdian, July 18, 2018, https://www. theguardian.com/world/2018/jul/18/spain-to-introduce-yes-means-yes-sexual-consent-law.

${ }^{30}$ See Meaghan Beatley, The Shocking Rape Trial that Galvanised Spain's Feminists - and the Far Right, THE GUARDIAN, Apr. 23, 2019, https://www.theguardian.com/world/2019/apr/23/wolf-pack-case-spain-feminism-far-right-vox.

${ }^{31}$ As already pointed out by Stephen Schulhofer. See Stephen Schulhofer, Consent: What It Means and Why It's Time to Require It, 47 U. PAC. L. REv. 665 (2016).

${ }^{32}$ See Consejo General del Poder Judicial, Informe sobre el Anteproyecto de Ley Orgánica de Garantía Integral de la Libertad Sexual (Feb. 25, 2021), https://www.poderjudicial.es/cgpj/es/Poder-Judicial/Consejo-General-del-Poder-Judicial/Actividaddel-CGPJ/Informes/Informe-sobre-el-anteproyecto-de-Ley-Organica-de-Garantia-Integral-de-la-Libertad-Sexual. For a view more favorable to the proposed reform, see Asociación de Mujeres Juezas de España, Propuestas de enmiendas al Proyecto de Ley Orgánica de Garantía Integral de la Libertad Sexual (Mar. 22, 2021), http://www.mujeresjuezas.es/wp-content/uploads/ 2021/04/ENMIENDAS-DEFINTIVO-VF.pdf.

${ }^{33}$ See Hörnle, supra note 1, at 1319-20; Aya Gruber, Not Affirmative Consent, 47 U. PAC. L. REV. 683-707 (2016).
} 
of making a choice or not. ${ }^{34}$ The radical wing of the feminist movement even argues that society is set up such that women are constantly oppressed and subordinated and, therefore, incapable of making a true consensual decision to engage in sexual intercourse. ${ }^{35}$ Without going that far, it would be enough to accept that the law's ability to recognize, let alone problematize, the way in which external conditions construct and constrain women's agency cannot be taken for granted. The starting point for the law to do so is to initiate a shift from the assumption that women consent if they do not say no, towards a requirement that there be some positive evidence of agreement. In spite of all the adverse criticism, only affirmative consent encourages women to play an equal role in the sexual relationship, giving female wishes equal weight to those of the male participant. At the same time, only affirmative consent encourages men to determine whether sex is actually desired by their partner, making clear that if a woman does not say or do anything to indicate free agreement, it is non-consensual and therefore prohibited sex. ${ }^{36}$

\section{III. "Sister, I believe you": The Lingering Introduction of the Gender Perspective}

During the trial, the five defendants were presented by their lawyers as good sons and friends, with their girlfriends and families displaying a supportive attitude. Unsurprisingly, the same gendered script was applied in understanding the female character and behavior of the victim. The attention given to accounts of false rape allegations by the men's lawyers placed emphasis on the victim's contradictory account of the facts and, therefore, her alleged lack of veracity. Furthermore, as shields to limit the extent to which the previous sexual history of victims can be disclosed in court have never been introduced in Spain, defense questioning of the victim focused on the woman's behavior before, during, and after the incident. Such a defense strategy is accepted and normalized, producing a significant focus on the victim's behavior. ${ }^{37}$ In the Wolf-Pack case, the act of rape was blamed on the victim, as if in some way she had provoked or tempted the male defendants with her behavior. She voluntarily walked with them, kissed one of them, entered the portal with them. It was she who was placed on trial, having to face long-held myths supporting a gendered understanding of a victim's behavior and responsibility, as if she were somehow negligent in letting rape happen. Capacity to consent was simply not considered an issue, despite the evidence of her alcoholic intoxication. ${ }^{38}$ Moreover, the ways that the victim found to help herself manage and survive the attack were trivialized and used to attack her credibility. Photos of the victim having fun with friends months after the alleged rape were considered as proof of her lack of suffering from rapeinduced trauma, silencing her capacity for autonomy and survival..$^{39}$ Across the protests, a consistent frustration emerged with the prejudiced assessments of the complainant's credibility that

\footnotetext{
${ }^{34}$ See Eithne Dowds, Towards a Contextual Definition of Rape: Consent, Coercion and Constructive Force, 83 MoD. L. REv. 35-63 (2020); Tanya Palmer, Distinguishing Sex from Sexual Violation: Consent, Negotiation and Freedom to Negotiate, in Consent: Domestic and Comparative Perspectives 9, 19 (Alan Reed, Michael Bohlander, Nicola Wake \& Emma Smith eds., 2017); Vanessa E. Munro, From Consent to Coercion: Evaluating International and Domestic Frameworks for the Criminalization of Rape, in RETHINKING RAPE LAW: INTERNATIONAL AND COMPARATIVE PERSPECTIVES 17, 26-27 (Clare McGlynn \& Vanessa E. Munro eds., 2010).

${ }^{35} \mathrm{See}$ Catharine A. MacKinnon, Feminism Unmodified: Discourses on Life and Law (1987); Catharine A. MacKinnon, Toward a Feminist Theory of State (1989); Catharine A. MacKinnon, Women's Lives, Men's Laws (2005).

${ }^{36}$ See Nicholas J. Little, From No Means No to Only Yes Means Yes: The Rational Results of an Affirmative Consent Standard in Rape Law, 58 VAND. L. REV. 1321-64 (2005).

${ }^{37}$ See Pilar Marco Francia, Victimización secundaria en los delitos sexuales, in LA MANADA: UN ANTES Y UN DESPUÉS EN LA Regulación de los Delitos Sexuales en España 308 (Patricia Faraldo Cabana \& María Acale Sánchez eds., 2018); Arantza Líbano, La delincuencia sexual y el papel de la víctima en el proceso penal, in LAS VOLENCIAS MACHISTAS CONTRA LAS MUJERES 41 (Ricardo Rodríguez \& Encarna Bodelón eds., 2011).

${ }^{38}$ See María Acale Sánchez, Violencia SeXual de Género Contra las Mujeres Adultas 220-21 (2019).

${ }^{39}$ See James Badcock, Pamplona 'Wolf Pack' Gang Rape Trial Angers Spain, BBC News, Nov. 28, 2017, https://www.bbc. com/news/world-europe-42149912.
} 
was exhibited by judges and lawyers involved in the case, which failed to live up to the necessary respect of the rights and dignity of the victim. "They don't believe us until they kill us" was shouted during the demonstrations, strengthening the calls for supporting the victim. ${ }^{40}$

In most Spanish cities, law enforcement agencies have established units specialized in violence against women, including rape. Police officers handling sexual assaults are trained to avoid aggressive questioning and disbelieving attitudes, encouraging victims' cooperation. Prosecutors and judges should also be trained in identifying the pervasive rape myths, traditional gender role attitudes, and sexism that may bias their legal reasoning and factual understanding. For the moment, this is not the case. Despite progress in public discourse and policy, prosecutorial and judicial training only marginally addresses equality issues, with no gender perspective. Prosecutorial and judicial responses to sexual assault cases remain riddled with problematic assumptions about gender and controversies over what counts as truth. As a consequence, women who are sexually assaulted regularly face prejudice on the part of the authorities who question their testimony. ${ }^{41}$ The widely publicized idea that women often lie and "cry wolf" about sexual assault as an act of revenge, or to hide their own inclination toward practices that some might label deviant, like group sex, affects prosecutors and judges' management of cases. The common assumption is that sexual assault accusations are frequently baseless and should be treated with extraordinary caution by the criminal justice system. ${ }^{42}$ Mass and social media networks perpetuate this myth. ${ }^{43}$ Such a prevalence reflects centuries-old attitudes portraying women as vengeful liars. ${ }^{44}$ Many people still believe that false allegations of rape are commonplace, confounding unfounded accusationsnamely, without enough evidence to prosecute or condemn-with false ones, not taking into account that in many cases in which prosecutors decide not to pursue the case or decide to settle the case, are influenced by gender stereotypes and rape myths. Expectations of victim and offender behaviors often follow a gender-specific path. For example, the appropriateness of women's behavior, and whether they thereby "merit" to be considered a victim of sexual assault, is a hot topic in the criminal justice system. Judicial concerns with risk management and risk burdens still lead to the judgment and rejection of complainants who are perceived as having engaged in risky behavior. As other gang-rape cases demonstrate, those women who fail to follow the rules of sexual safekeeping - because they chose to drink or get in a car with men or in any way allow themselves to get into a risky situation-are often denied protection. At the same time, the notion that a "real rape" must always involve a violent offender and a physically resistant victim may make some people believe that any other form of sexual assault does not violate the law, because it does not fit in this narrow definition of rape. ${ }^{45}$

\footnotetext{
${ }^{40}$ See Meaghan Beatley, 'Wolf Pack' Gang-Rape Verdict Spurs Thousands to Protest in Spain, GlobalPost, Apr. 26, 2018, https://www.pri.org/stories/2018-04-26/wolf-pack-gang-rape-verdict-spurs-thousands-protest-spain.

${ }^{41}$ As denounced by Amnistía Internacional. See Amnistía Internacional, No consiento. Basta de obstáculos para las víctimas de violencia sexual, https://www.es.amnesty.org/en-que-estamos/campanas/violencia-sexual-2018/. See also Adela Asúa Batarrita, El significado de la violencia sexual contra las mujeres y la reformulación de la tutela penal en este ámbito. Inercias jurisprudenciales, in GÉNERO, Violencia y DERECHO 131 (Patricia Laurenzo Copello, Luisa Maqueda Abreu \& Ana Rubio Castro eds., 2008); Maria Barcons, Encarna Bodelón, Jimena Martínez, Esther Murillo, Ariana Pisonero \& Patsilí Toledo, Las violencias sexuales en el Estado español: Marco jurídico y análisis jurisprudencial (Oct. 2018), https:// ddd.uab.cat/pub/infpro/2018/218654/diagnosis_libro_antigona_web.pdf.

${ }^{42}$ See Mathew S. Johnston, Ryan Coulling, \& Jennifer M. Kilty, Digital Knowledge Divides: Sexual Violence and Collective Emotional Responses to the Jian Ghomeshi Verdict on Twitter, 9 ANN. REV. INTERDISC. Just. RsCH. 167, 170-71 (2020).

${ }^{43}$ See Johnston et al., supra note 42, at 171; Ryan Coulling \& Matthew S. Johnston, The Criminal Justice System on Trial: Shaming, Outrage, and Gendered Tensions in Public Responses to the Jian Ghomeshi Verdict, 14 CRIME, MEDIA, CULTURE $311-$ 31 (2018).

${ }^{44}$ See Aya Gruber, Rape, Feminism, and the War on Crime, 84 WASH. \& LeE L. Rev. 581, 586 (2009); JAn JoRdAN, ThE Word of A Woman? Police, Rape And Belief (2004).

${ }^{45}$ See Emma Sleath \& Jessica Woodhams, Expectations About Victim and Offender Behavior During Stranger Rape, 20 Psych. Crime \& L. 798-820 (2014); Genevieve F. Waterhouse, Ali Reynolds \& Vincent Egan, Myths and Legends: The Reality of Rape Offenses Reported to a UK Police Force, 8 EUR. J. Psych. Applied to Legal ConteXt 1-10 (2015).
} 


\section{Towards a More Progressive Law on Sex Crimes in Spain?}

Before the Wolf-Pack case, other similar cases of gangs of young males assaulting teenage girls or young women did not make headlines. The Wolf-Pack case clearly induced a dramatic increase in news reporting on the phenomenon, with media coverage playing a pivotal role in public discourse. Through the Wolf-Pack case, a new generation of feminist journalists engaged in wider critiques of the societal attitudes that support and perpetuate not only rape, but all the many forms of violence and oppression of women. Sexual violence as a gender equality issue reappeared on the political agenda, opening the opportunity for legal reform. Lobbying and activism by women's groups and feminist organizations, in combination with a government which purports to pride itself on its gender-sensitive equality politics, have secured what is, at least, anticipated to be the uptake of a feminist-inspired rape law with a more progressive emphasis on consent. Spain's leftwing coalition cabinet approved a draft bill on the integral protection of sexual liberty on the eve of March 8, 2020, International Women's Day.

The "only yes is yes" draft bill—as the press called it ${ }^{46}$-makes clear that there has to be an "explicit expression of consent" by women if sexual acts are not to be considered crimes, and defines all non-consensual sex as sexual aggression. Rape is a subset of sexual aggression that includes penetration of the body in the absence of consent that violates sexual autonomy. But, as Cowan ${ }^{47}$ has emphasized, "consent is a concept which we can fill with either narrow liberal values, based on the idea of the subject as an individual atomistic rational choice maker, or with feminist values encompassing attention to mutuality, embodiment, relational choice and communication." One should not be too optimistic about the ways in which consent-based accounts will be interpreted and applied in legal practice.

To begin, the requirement of affirmative consent has already found strong opposition both in the judiciary ${ }^{48}$ and academia. ${ }^{49}$ One could ask if it is necessary. In other countries, moves towards a "yes means yes" model did not promote feminist arguments relating to sexual autonomy and the harmful nature of coerced sex. ${ }^{50}$ It is generally accepted, even among feminists, that reforms introducing affirmative consent have not proven practically successful. ${ }^{51}$ Rape is still widely underreported, and victims continue to be doubly traumatized by a trial. Feminists made gains in terms of specific legal reforms, but such changes were met with great resistance and undermined when put into practice.

Contrarily, abolition of the requirement of violence or intimidation in rape law seems to be relatively easier to accept. ${ }^{52}$ On one hand, it only means a comeback to the traditional, pre-

\footnotetext{
${ }^{46}$ See Isambard Wilkinson, Spain Tables 'Only Yes Means Yes' Rape Law, THE Times, Mar. 5, 2020, https://www.thetimes.co. $\mathrm{uk} /$ article/spanish-approves-the-only-yes-means-yes-rape-bill-jvtvb08gf.

${ }^{47}$ See Sharon Cowan, Freedom and Capacity to Make a Choice: A Feminist Analysis of Consent in the Criminal Law of Rape, in Sexuality and the Law: Feminist Engagements 51, 53 (Vanessa E. Munro \& Carl F. Stychin eds., 2007).

${ }^{48}$ See José Luis Ramírez Ortiz, Sociedad en red, igualdad, proceso y derecho penal. La sentencia de la Manada, 92 JUECES PARA la Democracia 11-25 (2018).

${ }^{49}$ See José Luis Díez Ripollés, Alegato contra un derecho penal sexual identitario, 21-10 REvisTA ELECTRÓNICA DE CIENCIA Penal y CRiminología 1-29 (2019); Francisco Muñoz Conde, La vinculación del juez a la ley y la reforma de los delitos contra la libertad sexual. Algunas reflexiones sobre el caso "La Manada", 43 Revista PenAL 290-99 (2019); Alicia Gil \& José Núñez Fernández, A propósito de "La Manada": análisis de la sentencia y valoración crítica de la propuesta de reforma de los delitos sexuales, 77 CRONISTA Estado Soc. 4-17 (2018).

${ }^{50}$ See Anna Carline \& Patricia L. Easteal, Shades of Grey-Domestic and Sexual Violence Against Women: LAW REFORM AND SOCIETy 165 (2014); Gruber, supra note 33; Lise Gotell, Rethinking Affirmative Consent in Canadian Sexual Assault Law: Neoliberal Sexual Subjects and Risky Women, 41 AKroN L. Rev. 865-98 (2008).

${ }^{51}$ See Gruber, supra note 44, at 626.

${ }^{52}$ See Patricia Faraldo Cabana, Razones para la reforma del delito de violación, in ClAves DE LA JUSTICIA PENAL. Feminización, Inteligencia Artificial, Supranacionalidad y Seguridad 177-204 (Silvia Barona Vilar ed., 2019); María Acale Sánchez, Tratamiento penal de la violencia sexual: la forma más primaria de violencia de género, in LA Manada: Un Antes y un Después en la Regulación de los Delitos SeXuales en España 71, 83-84, 91-93 (Patricia Faraldo Cabana \& María Acale Sánchez eds., 2018); Rosario de Vicente Martínez, El delito de violación: problemas que plantea
} 
1995 Spanish approach to the crime of rape. Besides that, the present definition of rape does not fall in line with the Istanbul Convention, of which Article 36 defines rape as sex without consent. Therefore, Spain has the obligation to implement a new legal definition of rape based on the lack of consent. But one change is not possible without the other. The abandonment of the violence or intimidation requirement alone is not sufficient to remedy the injustices of present rape law. Only combined may these changes result in increasing the reporting and conviction rates for rape in many cases where the victim is intoxicated or passed out and therefore incapable of consent, as well as in cases of child victims.

On the other hand, attitudes of disbelief and stigmatization towards victims of rape appear to be impervious to methodologically rigorous research, which estimates the number of false reports around $2 \%$ or lower in the United States and Commonwealth countries. ${ }^{53}$ Legal change does not help much in this regard, as these national experiences show. ${ }^{54}$ Empirical data and a progressive law reform alone cannot meet the challenges facing feminists seeking a change in both rape myths and judicial attitudes towards legislative reform.

The Wolf-Pack case created a window of opportunity for a more progressive legislation on sex crimes in Spain. Nevertheless, to ensure that the impact of the legal change does not remain at the level of the expressive, symbolic function of the law, it is necessary to change social and cultural norms that significantly affect prosecutorial and judicial practice and its outcomes, such as myths regarding the credibility of victims of sexual assault. ${ }^{55}$ According to its preamble, the draft bill recognizes this by integrating the gender perspective in all sectors related to the prevention, investigation, and prosecution of sexual violence. Shifting away from a legalist perspective centered only on how criminal law defines and penalizes rape and other forms of sexual harm, the draft bill in Spain focuses on the power and role of the law in defining and combatting rape, and also on the question of what other steps can be taken to prevent rape and promote desistance among perpetrators. It includes new comprehensive services available for victims, aimed at preventing trauma and re-victimization, as well as awareness measures for the citizenship at all levels of education and for all professionals involved in the processing of rape in the criminal justice system. It increases coordination between local, regional, and state agencies. It makes sure that involved institutions have protocols and models of best practices in place. Programs for ongoing education will be implemented, and mechanisms for policy development and for auditing the implementation and effectiveness of the various changes will be enacted. One can certainly say that this is a case where criminal justice approaches have not been prioritized over other policies.

\section{E. Conclusions}

The Wolf-Pack case represents a transformative moment for feminism in Spain. Dismal statistics tell a tale of a criminal justice system that, even with thoroughgoing revisions to its sex crimes laws, is failing to protect women from serious harms to their sexual autonomy. ${ }^{56}$ While the fallout

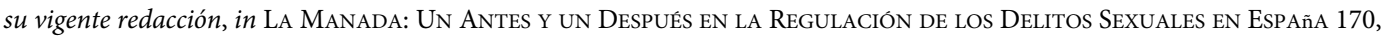
204-06 (Patricia Faraldo Cabana \& María Acale Sánchez eds., 2018). But see DíEz Ripollés, supra note 49.

${ }^{53}$ See Cassia Spohn \& Katharine Tellis, Policing and Prosecuting Sexual Assault: Inside the Criminal Justice System (2014); Kimberly A. Lonsway, Trying to Move the Elephant in the Living Room: Responding to the Challenge of False Rape Reports, 16 Violence Against Women 1356-71 (2010).

${ }^{54}$ See Clare McGlynn, Feminist Activism and Rape Law Reform in England and Wales, in RethinkING RAPE LAw: International AND Comparative Perspectives 139-51 (Clare McGlynn \& Vanessa E. Munro eds., 2010).

${ }^{55}$ See CARline \& EASTEAL, supra note 50 , at 170.

${ }^{56}$ Statistical data show that the number of rapes reported shot up from 1,249 in 2016 to 1,878 in 2019, breaking a decreasing tend since 2008. The figure is thought to be low, because of a deeply rooted culture of machismo that dissuades many victims from reporting sex crimes. According to Spain's Office of Violence Against Women, up to 80 percent of sexual assaults go unreported. Such a high attrition rate is not unusual in a comparative perspective. See Kathleen Daly \& Brigitte Bouhours, Rape and Attrition in the Legal Process: A Comparative Analysis of Five Countries, 39 CRIME JUST. 565-650 (2010); Jörg-Martin Jehle, Attrition and Conviction Rates of Sexual Offences in Europe: Definitions and Criminal Justice Responses, 18 EUR. J. CRIM.
} 
of the first two rulings in the Wolf-Pack case shows that collective feminist protest can eventually force change, reports of other gang rapes in Spain that have emerged in the past months demonstrate the political urgency of immediate reform, because the case law is marked by inconsistent judicial interpretations that reinforce not only a narrow understanding of sexual consent, but also a narrow understanding of individual responsibility and new forms of victim-blaming. Can the proposed rape law reform be seen as a positive outcome of the feminist-inspired protests?

Law is naturally conservative, ${ }^{57}$ and criminal courts often show a remarkable capacity to adjust to and effectively thwart well-intentioned reforms that fail to live up to their promise in terms of respecting the rights and dignity of rape victims. ${ }^{58}$ Therefore, it would be naive to simply trust in a legal reform. Other national experiences show that changing the law does not necessarily change the beliefs and behavior of victims, police, prosecutors, judges, and citizens, which may limit the effectiveness of progressive reform measures. The rhetoric of change may be proudly upheld while underlying structures and realities remain largely intact, demonstrating what has been identified as "the paradoxical way in which feminist knowledge both informs reform processes and is simultaneously disavowed." 59 Rape-law reform is not enough. Only by understanding the power and influence of the legal and judicial gendering strategies can we achieve a greater critical awareness of how, and under what circumstances, a gender-informed legal policy and practice development can challenge problematic stereotypes surrounding rape law. This approach must be combined with preventive measures linked to raising awareness and education to achieve positive and significant effects on women's protection against sexual violence. This is exactly the path taken by the draft bill, assuming that real changes need a long-term, broader perspective.

Nourse ${ }^{60}$ suggests that writing about feminist reform of criminal law is to write of simultaneous success and failure. We still do not know which one will prevail in relation to the intended reform. In any case, in the future, when legal scholars and sociologists will write about the history of sex crimes in Spain, they certainly will have to include the Wolf-Pack case in their narrative.

\footnotetext{
POL'y RsCH. 145-61 (2012); Katrin Hohl \& Elisabeth A. Stanko, Complaints of Rape and the Criminal Justice System: Fresh Evidence on the Attrition Problem in England and Wales, 12 EUR. J. CRIMINOLOGY 324-41 (2015). It is unclear whether the growth recorded by official statistical data represents an actual rise or a growing confidence among victims to report attacks. The public perception is that gang rape is increasing.

${ }^{57}$ Andrew E. TASlitz, Rape AND the Culture of the Courtroom 42 (1999).

${ }^{58}$ Gruber, supra note 44.

${ }^{59}$ Liz Kelly, The Everyday/Everynightness of Rape: Is it Different in War?, in GENDER, WAR, AND MILITARISM 114, 120 (Laura Sjoberg \& Sandra Via eds., 2010).

${ }^{60}$ Victoria Nourse, The "Normal" Successes and Failures of Feminism and the Criminal Law, 75 CHI. KENT L. REV. 951-78 (2000).
}

Cite this article: Faraldo-Cabana P (2021). The Wolf-Pack Case and the Reform of Sex Crimes in Spain. German Law Journal 22, 847-859. https://doi.org/10.1017/glj.2021.38 